\title{
REGULAMENTAÇÃO SOBRE BIO(IN)SEGURANÇA NO BRASIL: A QUESTÃO DOS ALIMENTOS TRANSGÊNICOS
}

\author{
Maria Clara Coelho Camara ${ }^{1}$ \\ Rubens Onofre Nodari ${ }^{2}$ \\ Maria Cristina Rodrigues Guilam ${ }^{3}$
}

\section{Resumo:}

Este estudo teve como objetivo analisar a legislação brasileira sobre organismos geneticamente modificados - OGMs (ou transgênicos). As normas foram identificadas nas bases de dados do SICON e LEXML, ambas disponíveis no site do Senado Federal. Foram localizadas 25 normas, sendo a maioria de autoria do Poder Executivo no governo Lula. Os principais temas debatidos foram plantio, fiscalização, comercialização e rotulagem dos OGMs. Conclui-se que a produção legislativa brasileira é, em sua maioria, baseada em medidas provisórias cujo objetivo principal foi autorizar a comercialização de soja GM plantada ilegalmente no país até 2003. As exigências brasileiras com relação à rotulagem assemelham-se à europeia, no entanto muito ainda necessita ser feito para melhorar as estratégias de fiscalização do cumprimento das normas. Normas brasileiras relevantes não foram identificadas pelas bases de dados utilizadas.

Palavras-chave: Transgênicos. Regulamentação. Segurança alimentar. Legislação.

\section{Considerações iniciais}

O século $X X$ foi palco de intenso desenvolvimento científico, destacando-se os avanços no campo da biotecnologia. As descobertas da estrutura da molécula de DNA e das enzimas de restrição levaram ao surgimento das técnicas do DNA recombinante (ARBIX, 2007), também denominada de engenharia genética. É oportuno observar que o avanço de certas biotecnologias como a transgenia e a

\footnotetext{
${ }^{1}$ Doutora em Saúde Pública pela Escola Nacional de Saúde Pública, da Fundação Oswaldo Cruz, Fiocruz, Rio de Janeiro, RJ, Brasil. Assistente administrativo da Fundação Carlos Chagas Filho de Amparo à Pesquisa do Estado do Rio de Janeiro, RJ, Brasil. E-mail: mclaracc@gmail.com.

${ }^{2}$ Doutor em Genética - University of California at Davis, EUA. Professor Titular da Universidade Federal de Santa Catarina, Florianópolis, Santa Catarina, SC, Brasil. Centro de Ciências Agrárias, Departamento de Fitotecnia. E-mail: nodari@cca.ufsc.br.

${ }^{3}$ Doutora em Saúde Coletiva pela Universidade do Estado do Rio de Janeiro, Rio de Janeiro, RJ, Brasil. Tecnologista da Fundação Oswaldo Cruz, Fiocruz. Pesquisadora do Centro de Estudos de Saúde do Trabalhador e Ecologia Humana da Fiocruz, Rio de Janeiro, RJ, Brasil. E-mail: guilam@fiocruz.br.
}

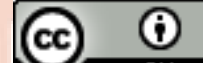


clonagem vem acompanhado de debates e controvérsia envolvendo principalmente a comunidade científica, os governantes, bem como a população em geral. A capacidade do homem em manipular e, consequentemente, interferir no curso natural da evolução dos seres vivos, inclusive do próprio ser humano, torna a tecnologia do DNA recombinante uma tecnologia ao mesmo tempo popular e polêmica.

Os diversos interesses econômicos, o grande número de cientistas envolvidos e a grande quantidade de estudos apontando tanto situações de riscos como benefícios alimentam tal polêmica. Como assinala Lacey (2006, p.31), "a falta de clareza que envolve essas questões [relacionadas aos OGMs] revela que estão em jogo valores, interesses e modos de vida fundamentalmente opostos”. Leite (2007, p.41-47) ressalta que só a comunidade científica é capaz de desconstruir as controvérsias em torno dos transgênicos, mas que, para tanto, "seria preciso que essas lideranças recuperassem a independência e deixassem de se perfilar por trás de um grupo e de uma comissão como se eles fossem os únicos arautos da razão". No entanto, outros autores admitem que biossegurança diz respeito aos interesses da sociedade, por envolver a vida humana, a sua dignidade e o meio ambiente (VIANA e TEXEIRA, 2009).

As consequências das decisões, ou indecisões, políticas sobre biossegurança dos transgênicos afetam diretamente a sociedade. Mais do que objeto biológico, os transgênicos também são objetos socioeconômicos, uma vez que se configuram em mercadoria com necessidade de propriedade intelectual (LACEY, 2007). Também são objetos de acordos internacionais de importação e exportação de produtos reforçando os interesses econômicos. Aspectos éticos, morais e culturais também permeiam as consequências do uso de transgênicos. Portanto, a normatização dos transgênicos deve ter em vista a segurança da população priorizando-a em detrimento dos interesses econômicos. Envolvem ainda outras políticas públicas sobre os distintos aspectos decorrentes da produção e uso de transgênicos.

A capacidade de construir um regime de regulação que assegure a confiança pública e que busque um equilíbrio entre a precaução e a inovação tecnológica é reconhecida como um desafio. Construir um sistema de normatização da biossegurança é uma tarefa multidisciplinar cuja essência encontra-se em uma desejável integração entre as ciências biológicas e as ciências sociais, pois a 
aplicação da tecnologia não é somente uma questão técnica. Tal aplicação envolve responsabilidade social e precaução ambiental (VICTORINO, 2004).

Este artigo pretende investigar a regulamentação dos organismos geneticamente modificados no Brasil. Para tanto, foi reunida e analisada a legislação sobre OGM disponível em duas bases de dados do Governo Federal. O objetivo principal é buscar compreender como são regulamentados os OGMs no País e suas principais diferenças com relação à regulamentação de outros países.

O cultivo, a comercialização e o consumo de alimentos transgênicos e sua inserção no Brasil foi, e ainda é, um assunto polêmico. No Brasil, sua regulamentação envolveu uma construção cercada de indecisões e conflitos. Assim, diversas Medidas Provisórias e Leis (e seus respectivos decretos regulamentadores), entre outros, foram aprovadas e sancionadas, demonstrando a importância da discussão sobre a construção desse marco teórico e, consequentemente, justificando a importância do presente estudo.

Há uma longa discussão sobre as consequências do uso e do não uso dos transgênicos. Como se trata da produção de alimentos em escala mundial e, não vivemos sem alimentos, sua problemática deve ser abordada com muita cautela, pois as consequências, se ocorrerem, serão irreversíveis. Embora o número de estudos científicos aponta possíveis riscos à saúde humana e ao meio ambiente, ainda não há consenso sobre o assunto. Com isso, este estudo busca contribuir para a compreensão de como a regulamentação dos transgênicos ocorreu no Brasil, descrevendo-a e comparando-a com as de outras nações.

\section{Caminho metodológico}

Para a realização deste estudo recorreu-se as bases de dados SICON e LEXML, ambas disponíveis no site oficial do Senado Federal Brasileiro, utilizando-se os descritores "transgênico(s)" e "OGM(s)". O período utilizado para a busca foi de 1995, início da regulamentação dos transgênicos no Brasil, a 2009.

SICON é o Sistema de Informações do Congresso Nacional e oferece diversas maneiras de encontrar informações referentes à atividade legislativa e regulamentações em um único banco de dados. LEXML é um portal especializado em informações legislativa e jurídica, onde estão reunidos leis e decretos entre outros documentos das esferas federal, estadual e municipal dos Poderes Executivo, 
Legislativo e Judiciário de todo o Brasil. Criado em 2008, seu objetivo é organizar a informação legislativa e jurídica de forma digital pelos vários órgãos dos três Poderes (LIMA e CICILIATI, 2008). Apesar disso, LEXML reúne normas anteriores a sua criação.

As normas encontradas foram inicialmente organizadas segundo seu tema principal e autoria (Quadro 1) e, posteriormente, realizou-se uma análise sobre tais temas, onde se contextualizou as posições do Brasil no cenário internacional.

Quadro 1: Normas sobre Transgênicos no Brasil do período de 1995 a 2009

\begin{tabular}{|c|c|c|}
\hline Norma & Autoria & Temas envolvidos \\
\hline Lei n 8.974, de 5/01/95 & $\mathrm{PL}$ & $\begin{array}{l}\text { Normas de plantio, fiscalização e/ou } \\
\text { comercialização }\end{array}$ \\
\hline Lei $n^{\circ} 13494$, de 5/04/00 & Estadual (MG) & Rotulagem de OGM \\
\hline Decreto $n^{\circ} 3.871$, de 18/07/01 & $\mathrm{PE}$ & Rotulagem de OGM \\
\hline Lei $n^{\circ} 14127$, de 14/12/01 & Estadual (MG) & Rotulagem de OGM \\
\hline Decreto $n^{\circ} 4.602$, de 21/02/03 & $\mathrm{PE}$ & $\begin{array}{l}\text { Normas para plantio, fiscalização } \\
\text { e/ou comercialização }\end{array}$ \\
\hline Lei $n^{\circ} 10.688$, de 13/06/03 & $\mathrm{PL}$ & $\begin{array}{l}\text { Normas para plantio, fiscalização } \\
\text { e/ou comercialização }\end{array}$ \\
\hline $\begin{array}{l}\text { Medida Provisória } n^{\circ} 113 \text {, de } \\
\qquad 26 / 03 / 03\end{array}$ & $\mathrm{PE}$ & $\begin{array}{l}\text { Normas para plantio, fiscalização } \\
\text { e/ou comercialização }\end{array}$ \\
\hline Decreto $n^{\circ} 4.680$, de $24 / 04 / 03$ & $\mathrm{PE}$ & Rotulagem de OGM \\
\hline $\begin{array}{c}\text { APN } 0 \text { de } 21 / 05 / 2003-\text { ATO } \\
\text { DO CN }\end{array}$ & $\mathrm{PL}$ & $\begin{array}{l}\text { Normas para plantio, fiscalização } \\
\text { e/ou comercialização }\end{array}$ \\
\hline $\begin{array}{l}\text { Medida Provisória } \mathrm{n}^{\circ} 131 \text {, de } \\
25 / 09 / 03\end{array}$ & $\mathrm{PE}$ & $\begin{array}{l}\text { Normas para plantio, fiscalização } \\
\text { e/ou comercialização }\end{array}$ \\
\hline Decreto $n^{\circ} 4.846$, de 25/09/03 & $\mathrm{PE}$ & $\begin{array}{l}\text { Normas para plantio, fiscalização } \\
\text { e/ou comercialização }\end{array}$ \\
\hline $\begin{array}{c}\text { APN } 0 \text { de } 19 / 11 / 2003-\text { ATO } \\
\text { DO CN }\end{array}$ & $\mathrm{PL}$ & $\begin{array}{l}\text { Normas para plantio, fiscalização } \\
\text { e/ou comercialização }\end{array}$ \\
\hline Lei $n^{\circ} 10.814$, de 15/12/03 & PL & $\begin{array}{l}\text { Normas para plantio, fiscalização } \\
\text { e/ou comercialização }\end{array}$ \\
\hline
\end{tabular}




\begin{tabular}{|c|c|c|}
\hline $\begin{array}{l}\text { Medida Provisória } \mathrm{n}^{\circ} 223 \text {, de } \\
14 / 10 / 04\end{array}$ & $\mathrm{PE}$ & $\begin{array}{l}\text { Normas para plantio, fiscalização } \\
\text { e/ou comercialização }\end{array}$ \\
\hline Decreto $n^{\circ} 5.250$, de 21/10/04 & $\mathrm{PE}$ & $\begin{array}{l}\text { Normas para plantio, fiscalização } \\
\text { e/ou comercialização }\end{array}$ \\
\hline $\begin{array}{c}\text { APN } 0 \text { de } 08 / 12 / 2004-\text { ATO } \\
\text { DO CN }\end{array}$ & $\mathrm{PL}$ & $\begin{array}{l}\text { Normas para plantio, fiscalização } \\
\text { e/ou comercialização }\end{array}$ \\
\hline Lei $n^{0} 11.092$, de 12/01/05 & $\mathrm{PL}$ & $\begin{array}{l}\text { Normas para plantio, fiscalização } \\
\text { e/ou comercialização }\end{array}$ \\
\hline Lei $n^{\circ} 11.105$, de 24/03/05 & $\mathrm{PL}$ & $\begin{array}{l}\text { Normas para plantio, fiscalização } \\
\text { e/ou comercialização }\end{array}$ \\
\hline Decreto $n^{\circ} 5.534$, de 6/09/05 & $\mathrm{PE}$ & $\begin{array}{l}\text { Normas para plantio, fiscalização } \\
\text { e/ou comercialização }\end{array}$ \\
\hline Decreto $n^{\circ} 5.591$, de 22/11/05 & $\mathrm{PE}$ & $\begin{array}{l}\text { Normas para plantio, fiscalização } \\
\text { e/ou comercialização }\end{array}$ \\
\hline Decreto $n^{\circ} 5.950$, de 31/10/06 & $\mathrm{PE}$ & $\begin{array}{l}\text { Normas para plantio, fiscalização } \\
\text { e/ou comercialização }\end{array}$ \\
\hline Lei $n^{0} 11.460$, de 21/03/07 & $\mathrm{PL}$ & $\begin{array}{l}\text { Normas para plantio, fiscalização } \\
\text { e/ou comercialização }\end{array}$ \\
\hline Decreto $n^{\circ} 5.891$, de 11/09/06 & $\mathrm{PE}$ & $\begin{array}{l}\text { Normas para plantio, fiscalização } \\
\text { e/ou comercialização }\end{array}$ \\
\hline $\begin{array}{l}\text { Medida Provisória } \mathrm{n}^{\circ} 327 \text {, de } \\
\text { 31/10/06 }\end{array}$ & $\mathrm{PE}$ & $\begin{array}{l}\text { Normas para plantio, fiscalização } \\
\text { e/ou comercialização }\end{array}$ \\
\hline Lei no 18031 , de 12/01/09 & Estadual (MG) & $\begin{array}{l}\text { Normas para plantio, fiscalização } \\
\text { e/ou comercialização }\end{array}$ \\
\hline
\end{tabular}

Fonte: CAMARA, 2012.

$\mathrm{PE}=$ Poder Executivo $-\mathrm{PL}=$ Poder Legislativo $-\mathrm{APN}=$ Ato do Presidente do Congresso

\section{Características do poder político brasileiro}

O Brasil é uma federação com 26 estados e um Distrito Federal, com eleições diretas em 3 níveis (federal, estadual e municipal). Tem eleições de dois em dois anos não totalmente coincidentes (FLEISCHER, 2004).

O contexto institucional brasileiro vem mudando desde a reforma do Estado, da abertura da economia e da integração do país através da globalização $(\mathrm{BOSCHI}$ e 
LIMA, 2003). No que se refere ao sistema político observa-se uma capacidade governativa, através das seguintes funções: ser capaz de identificar problemas da sociedade e formular políticas públicas, isto é, oferecer soluções; e implementar as políticas formuladas mobilizando, para isso, meios e recursos políticos, organizacionais e financeiros necessários (SANTOS, 1997).

O poder político brasileiro é composto de 3 poderes, o Executivo, o Legislativo e o Judiciário. A doutrina da separação de Poderes prescreve a autonomia dos Poderes, das funções e das pessoas como os elementos necessários ao controle horizontal conducente à restrição do abuso do poder. No entanto, destaca-se que o Executivo predomina durante o processo legislativo no que se refere à formulação das políticas, sendo raros os projetos de lei de iniciativa do Congresso Nacional (SANTOS, 1997; BAPTISTA, 2010). Isso foi observado no presente estudo, onde a maioria das normas foi de autoria do Poder Executivo.

Durante o século $\mathrm{XX}$, observou-se um movimento de transferência gradativa da iniciativa da legislação para o Poder Executivo. Além disso, verificou-se uma transformação na natureza da lei que, de comando normativo estatal proveniente do Legislativo e dotado das características de generalidade, tornou-se, na maioria dos casos, instrumento de governo dotado de escopo específico. Cabe ao Legislativo a responsabilidade final pela aprovação das leis e o aperfeiçoamento dos mecanismos de controle e fiscalização, em alguns casos, com a parceria do Poder Judiciário (PESSANHA, 2003).

A elaboração de leis é o item mais importante das relações entre o Legislativo e o Executivo. O Congresso Nacional (CN) é a instituição responsável por exercer o poder legislativo na esfera federal e tem como principal atividade legislar e fiscalizar os demais Poderes (Executivo e Judiciário) (BRASIL, 1988). Foi instituído desde a Constituição de 1891 e é composto por duas Casas, a Câmara dos Deputados (CD), representação imediata da população e o Senado Federal (SF), Casa que representa os Estados e o Distrito Federal (DULCl, 2003).

A Constituição Federal (CF) 88 confere ao chefe do Poder Executivo amplos poderes sobre a administração pública. O principal é o que dá ao presidente a faculdade de nomear e demitir livremente os ministros de Estado. Outro aspecto que merece destaque é o fato do presidente ter o poder de editar medidas provisórias (MPs), o que confere ao chefe do Executivo um controle sobre o processo legislativo. Em posse dessa prerrogativa, o Poder Executivo vem utilizando as 
medidas provisórias para tratar dos mais variados temas, contrariando a determinação legal de utilizá-las somente em casos de urgência e relevância (AMORIM, 2004), Foram editadas 2.230 MPs no período de 1988 a 2001 e 543 entre os anos de 2001 a 2011 (BRASIL, 2011). Sobre alimentos transgênicos, foram editadas 4 medidas provisórias num período de 4 anos (de 2003 a 2006).

A medida provisória é uma forma de legislação de emergência criada pela Constituição Federal de 1988 para substituir o decreto-lei das Cartas anteriores. Apesar de permitida, seu uso imoderado suscitou um debate permanente desde o início da vigência da atual Constituição. Deste modo, sua edição, que em tese está condicionada à excepcionalidade de eventos relevantes e urgentes passa a ser utilizada em várias situações distintas (PESSANHA, 2003). No caso dos transgênicos, o que se observou claramente foi o uso, em demasia, das Medidas Provisórias como instrumento de gestão de produtos decorrentes do uso da tecnologia do DNA recombinante.

Embora a CF não tenha, a princípio, estipulado diretamente as matérias insuscetíveis de serem tratadas pelas medidas provisórias, há um consenso de que elas não podem desrespeitar os limites estabelecidos para a delegação legislativa ordinária. Ressalta-se que as medidas provisórias suspendem, mas não revogam, a vigência de normas anteriores e não criam novas. Desse modo, o conteúdo da medida provisória passa a ter força de lei, modificando dessa maneira a situação anterior à sua vigência (PESSANHA, 2003). Para tanto, é necessário que a MP seja aprovada no CN, caso contrário perde sua importância.

\section{A bio(in)ssegurança no Brasil}

Foram identificadas 25 normas sobre transgenia nas bases de dados pesquisadas. Destas, 9 leis, 9 decretos, 4 medidas provisórias e 3 atos do presidente do Congresso Nacional (Quadro 1).

Ressalta-se que o arcabouço legal que regulamenta os transgênicos no Brasil também é composto de Resoluções da CTNBio e do CNBS bem como de Instruções Normativas, Orientações e portarias da CTNBio que não fazem parte das bases pesquisadas. Após levantamento verificou-se que a produção legislativa sobre transgênicos concentra-se no governo Lula (21 das 25 normas), considerando 7 anos para cada governo (FHC de 1995 à 2002 e Lula de 2003 à 2009) (Tabela 1). 
Além disso, observa-se a concentração de normas no ano de 2003 . Tal fato se justifica uma vez que 2003 foi o ano de início de tramitação da nova lei de biossegurança e da edição da $1^{a}$ medida provisória autorizando a comercialização da safra de soja ilegal.

Tabela 1: Produção Legislativa sobre transgênicos no período de 1995 a 2009

Fonte: CAMARA, 2012.

Sobre o conteúdo dessas normas, os temas plantio, fiscalização, comercialização e rotulagem foram os assuntos mais debatidos e regulados no campo político. Sendo as Leis no 11105 de 2005 e n 11460 de 2007 e o Decreto $n^{\circ}$ 4680 de 2003 as principais normas em vigor até agosto de 2012 (BRASIL, 2005; 2007; 2003a).

Algumas normas que regulamentam os transgênicos não estão inseridas nessas bases de dados, como a Portaria $n^{\circ} 2.658$ de 2003 e outras normas aprovadas por diferentes estados brasileiros (BRASIL, 2003b). É o caso da Lei $n$ 12.128, de 15 de janeiro de 2002, do Estado de Santa Catarina (BRASIL, 2002). A ausência dessas normas configura-se em uma limitação nessas bases de dados.

-Plantio, fiscalização e comercialização dos OGMs

\begin{tabular}{|c|c|c|c|c|c|c|}
\hline Governos & Ano & \begin{tabular}{|c|} 
Medidas \\
Provisórias
\end{tabular} & Leis & Decreto & APN & Total \\
\hline $\mathrm{FHC}$ & 1995 & 0 & 1 & 0 & 0 & 1 \\
\hline FHC & 2000 & 0 & 1 & 0 & 0 & 1 \\
\hline FHC & 2001 & 0 & 1 & 1 & 0 & 2 \\
\hline Lula & 2003 & 2 & 2 & 3 & 2 & 9 \\
\hline Lula & 2004 & 1 & 0 & 1 & 1 & 3 \\
\hline Lula & 2005 & 0 & 2 & 2 & 0 & 4 \\
\hline Lula & 2006 & 1 & 0 & 2 & 0 & 3 \\
\hline Lula & 2007 & 0 & 1 & 0 & 0 & 1 \\
\hline Lula & 2009 & 0 & 1 & 0 & 0 & 1 \\
\hline $\begin{array}{l}\text { R.Inte } \\
\text { Total }\end{array}$ & & & $\begin{array}{l}\text { is, } \\
9\end{array}$ & & 3 & 25 \\
\hline
\end{tabular}


A introdução de sementes transgênicas no Brasil foi palco de muitas discussões. Até o ano de 2003, o País manteve - no âmbito de seu marco regulatório - uma posição contrária a tais produtos, gozando, com isso, de todos os prestígios econômicos de ter a Europa como principal comprador de soja. Entretanto, o aumento significativo do cultivo clandestino de soja transgênica, no mesmo ano, e a demora na publicação de uma nova lei (Lei $n^{\circ}$ 11105) (BRASIL, 2005), levaram a publicação de 3 Medidas Provisórias autorizando o cultivo das safras de 2003, 2004 e 2005 (MP no 113, n 131, n 223 e n 327) (BRASIL, 2003c; 2003d; 2004a; 2006). É importante relatar que através da edição dessas três Medidas Provisórias, o poder Executivo descumpre as determinações da Constituição Federal de 1988 (artigo 225) e da Lei de Biossegurança, em vigor na época (Lei $n^{\circ}$ 9.874), que estabeleciam mecanismos de segurança para as sementes transgênicas (BRASIL, 1988; 1995). A edição dessas MPs gerou uma série de desdobramentos legais, que vieram a representar 13 das 25 normas que regulamentam os transgênicos.

Em ordem cronológica, as MPs 113, 131, 223, 327 foram convertidas nas leis $n^{\circ} 10.688$ de 2003, a de $n^{\circ} 10.814$ de 2003, a de n 11.092 de 2005 e a de $n^{\circ} 11.460$ de 2007, respectivamente (BRASIL, 2003e; 2003f; 2007a).

A Lei $n^{\circ} 10.688$, de 2003, resultou da primeira Medida Provisória ( $\left.n^{\circ} 113\right)$ editada pelo presidente Luiz Inácio Lula da Silva para liberar a comercialização do cultivo ilegal da safra de 2002/2003 de soja GM. Já a segunda lei, a de $n^{\circ} 10.814$ de 2003 (originária da MP $n^{\circ}$ 131) faz exatamente igual a $1^{\text {a }}$, autorizando a comercialização da safra de 2003/2004.

A terceira lei, a 11.092 de 12 de janeiro 2005 (BRASIL, 2005b), também estabelecia normas para o plantio e comercialização da produção de soja geneticamente modificada, para a safra de 2004/2005, originária da Medida Provisória $n^{\circ}$ 223. Através da Lei $n^{\circ}$ 11.092, de 2005 o governo libera a comercialização e o consumo ao mesmo tempo em que considera, paradoxalmente, os OGM inseguros conforme o artigo $5^{\circ}$, que afirma "os produtores de soja GM que causarem danos ao meio ambiente e a terceiro, inclusive quando decorrentes de contaminação por cruzamento, responderão, solidariamente pela indenização ou reparação integral do dano". 
A Lei no 11.105 de 2005 (BRASIL, 2005a) estabelece normas de segurança e mecanismos de fiscalização de atividades que envolvam OGM e seus derivados, cria o Conselho Nacional de Biossegurança (CNBS), reestrutura a Comissão Técnica Nacional de Biossegurança (CTNBio) e dispõe sobre a Política Nacional de Biossegurança (PNB), entre outras determinações. Atualmente, é a principal lei que regulamenta a plantação, comercialização e consumo dos transgênicos no Brasil. É considerada como "nova" lei de biossegurança, pois revoga a Lei nº 8.974 de 1995, considerada a primeira lei de biossegurança do Brasil. Além disso, essa lei autorizou definitivamente a liberação comercial do cultivo de soja $\mathrm{GM}$, estabelecendo dispositivos gerais para a aprovação de OGM e seus derivados mesmo na ausência de apresentação do Estudo de Impacto Ambiental e o Relatório de Impacto no Meio Ambiente (EIA/RIMA), uma exigência constitucional.

A promulgação dessa nova lei redefine a estrutura de competências administrativas, através da designação de três instâncias para regular os organismos transgênicos: o CNBS que se configura como instância superior de decisão; a CTNBio, segunda instância de decisão e, por fim, os Ministérios da Saúde (MS), Agricultura, Pecuária e Abastecimento (MAPA) e do Meio Ambiente (MMA), como órgãos de registros e fiscalização e a Secretaria Especial de Aquicultura e Pesca (SEAP) como órgão de registro.

A CTNBio, apesar de segunda instância, passa a ser o principal órgão de regulamentação dos organismos transgênico e, por isso, é alvo de muitas críticas (MARINHO; MINAYO-GOMEZ, 2004; DOLABELLA; ARAÚJO; FARIA, 2005). Entre as críticas feitas à CTNBio, encontra-se a necessidade de maior participação da sociedade civil e maior publicidade para os processos de autorização, licenciamento e registro dos OGMs. Outras críticas referem-se à atuação dessa Comissão em liberações comerciais anteriores à Lei $n^{\circ} 11.105$ (MARINHO e MINAYO-GOMEZ, 2004; DOLABELLA, ARAÚJO e FARIA, 2005).

Para embasar as críticas referentes à atuação da Comissão, destacam-se algumas deliberações. Em 1998, a CTNBio emitiu parecer favorável à empresa multinacional Monsanto autorizando o plantio em escala comercial da soja $R R$ sem a realização de estudo de impacto ambiental, considerado obrigatório pela Constituição Federal. Curiosamente, em 2005, sete dias antes da promulgação de Lei $n^{0} 11.105$, a CTNBio concedeu autorização para produção comercial do algodão transgênico BOLLGARD, declarando que a atividade em questão não envolvia risco 
que justificasse o Estudo de Impacto Ambiental (CTNBio Parecer $n^{\circ} 513$ ) (BRASIL 2005c).

Outra liberação comercial que merece destaque é a do caso da vacina VAXXITEK MD/IBD, uma vacina viva (de vírus) recombinante contra a doença de Marek e doença de Gumboro, amplamente utilizada em frangos. Na época, o Processo 01200.005090/2003-92 foi considerado totalmente confidencial, caráter este estendido ao Parecer Técnico nº 099/2004 da CTNBio (CTNBio Parecer nº 099) (BRASIL, 2003). Nem mesmo na página da internet da empresa detentora da tecnologia a natureza transgênica do produto comercial é mencionada. Até agosto de 2011, a CTNBio emitiu parecer técnico conclusivo liberando comercialmente 17 cultivares de milho, 9 de algodão e 4 de soja, além de 11 vacinas, um microorganismo e uma enzima, totalizando 43 liberações, sem a exigência de realização de estudos de longo prazo que atestem a real segurança desses produtos (BRASIL, 2005c). Cumpre lembrar que a decisão final relativa à disseminação voluntária de plantas GM no meio ambiente é feita por parlamentares que representam os ministérios, através do CNBS (FERMENT, 2008).

Outra importante norma em vigor é a Lei $n^{0} 11.460$ de 2007, originária de Medida Provisória $\mathrm{n}^{\circ} 327$ de 2006. Dispõe, entre outros, sobre o plantio de OGM em unidades de conservação, vedando sua pesquisa e seu cultivo nas terras indígenas e áreas de unidades de conservação, exceto nas Áreas de Proteção Ambiental. Também faz parte da lei a alteração do quorum de votação da CTNBio.

A Lei $n^{0} 11.460$ tratou de três assuntos completamente distintos. Inicialmente, referia-se apenas às medidas de controle da plantação de transgênicos em terras indígenas e em unidades de conservação. Durante sua tramitação, ocorreram emendas que incluíram a redução do quorum da CTNBio para a tomada de decisão e beneficiamento e comercialização das fibras de algodão GM plantadas ilegalmente. Cabe ressaltar que só o artigo sobre o algodão GM foi vetado pelo Presidente da República argumentando que autorizar essa comercialização representa perigoso precedente para a atividade de fiscalização do uso de Organismos Geneticamente Modificados - OGM não autorizados no País. A sua aprovação seria interpretada como flexibilização do Poder Executivo para as atividades irregulares com OGM (Mensagem no 164 de 21 de março de 2007) (BRASIL, 2007b). Tal justificativa contraria a postura que o governo assumiu desde 
2003, com a edição de três MPs ( $n^{\circ} 113, n^{\circ} 131$ e $\left.n^{\circ} 223\right)$ que justamente legalizam plantações ilegais.

Não se pode deixar de considerar que é característica, e esperado, na dimensão estratégica do jogo político, a contradição e a mudança de opinião. São vários os atores envolvidos e fatores por detrás de uma decisão política, com isso, as decisões variam durante a busca de coalizões para concretização de alianças.

Com relação ao quorum da CTNBio, verificou-se uma redução absoluta de 18 para 14 votos necessários para uma aprovação comercial de qualquer OGM. A redução repercutiu em mais uma liberação comercial; o milho tolerante a herbicida da Bayer Crop Science - Evento T 25 (Parecer técnico n 987) (BRASIL, 2007). Essa autorização foi emitida na $102^{a}$ Reunião da Comissão que ocorreu em menos de dois meses após a publicação da Lei n 11.460 de 2007 em Diário Oficial da União.

Uma das poucas certezas que se tem sobre a regulamentação dos alimentos transgênicos é que as normas não se baseiam em um princípio específico e sim são pautadas na avaliação caso a caso, diferente dos Estados Unidos (EUA) e da União Europeia (UE) que tem seus princípios claramente adotados.

No cenário internacional, existem diferenças significativas na forma como cada país regulamenta os alimentos transgênicos. Tais diferenças muitas vezes configuram-se na adoção de princípios totalmente opostos, como o Princípio da Precaução (PP) e o critério da Equivalência Substancial (ES) (RIZZI, SORLINI e DAFFONCHIO, 2004).

Nos EUA, os OGMs são considerados aditivos alimentares e regulados com base no critério da equivalência substancial, ou seja, caso o produto geneticamente modificado seja substancialmente equivalente ao convencional, não há necessidade de mais estudos. As agências envolvidas na regulamentação dos transgênicos nos EUA são a Food and Drug Administration (FDA), a Environmental Protection Agency (EPA) e a United States Departament of Agriculture (USDA). Destas, a FDA tem a maior atuação no processo de avaliação dos OGMs (PELAEZ e SBICCA, 2010).

$\mathrm{Na}$ UE, os alimentos transgênicos são considerados como novos alimentos e com isso são submetidos a um processo de avaliação com base nas determinações do Regulamento 258/1997 (DAVISON, 2010). Os OGMs também estão sobre as determinações dos Regulamentos 1829/2003; 1830/2003; 1946/2003 e das Diretivas 2001/18/EC e 90/219/EEC (EUROPEAN COMMISSION, 2006). O Princípio que 
permeia a regulação dos transgênicos na UE é o do PP, que defende que diante das incertezas a postura mais adequada é a da precaução (GRUĖRE, 2006).

Adotado pela Convenção sobre Diversidade Biológica (CDB), o PP essencialmente preconiza "que quando exista ameaça de sensível redução ou perda de diversidade biológica, a falta de plena certeza científica não deve ser usada como razão para postergar medidas para evitar ou minimizar essa ameaça”. Assim, a adoção do Princípio da Precaução, se constitui em alternativa concreta a ser adotada diante de incertezas científicas (CAMARA et al., 2009). Embora explicitado no Art. 1 da Lei de Biossegurança, o mesmo vem sendo ignorado (ZANONI, 2011).

O não cumprimento do PP se constitui numa aventura, cujas consequências não são possíveis de serem antecipadas. Exemplo disso foi em 2011 a constatação da presença da toxina BT do milho transgênico MON810, em sangue de mulheres grávidas e seus fetos (ARIS e LEBLANC, 2011).

\section{-Rotulagem de alimentos transgênicos}

A rotulagem dos produtos transgênicos vem sendo, ao longo dos últimos anos, objeto de acirradas discussões. A principal questão levantada pela indústria de alimentos é que a rotulagem de tais produtos representaria um acréscimo nos custos. No entanto, independente do aspecto econômico deve-se considerar que a regulação de normas de rotulagem é de fundamental importância para assegurar o direito à informação. Além disso, uma adequada rotulagem permite a rastreabilidade de um determinado produto, assegurando controle mais efetivo (biovigilância), em casos de contaminação alimentar.

Para exemplificar a importância do rastreamento, através de uma rotulagem adequada, relata-se o caso do milho GM StarLink e do suplemento alimentar transgênico L-tripofano. O primeiro contaminou a cadeia de alimentos dos EUA, com a suspeita de que as propriedades da proteína transgênica pudessem desencadear reações alérgicas. Já no caso de L-triptofano, foram afetadas mais de 10 mil pessoas, com cerca de 100 mortos, porque não trazia no rótulo os possíveis perigos. Como não é obrigatória a identificação de transgênicos na rotulagem nos EUA foi difícil rastrear o problema e, consequentemente, respeitar o direito do consumidor (ALMEIDA JÚNIOR e MATTOS, 2005). 
Outra questão que legitima a importância da rotulagem é o direito de fornecer ao consumidor informação adequada sobre o produto que pretende consumir (PESSANHA e WILKISON, 2005). O artigo $6^{\circ}$ do Código de Defesa do Consumidor, Lei $\mathrm{n}^{\circ} 8.078$ de 1990, determina que é direito básico do consumidor ter acesso à “... informação adequada e clara sobre os diferentes produtos e serviços, com especificação correta de quantidade, características, composição, qualidade e preço, bem como sobre os riscos que apresentem" (BRASIL, 1990).

No que se refere à rotulagem de alimentos de origem transgênica, estão em vigor no Brasil o Decreto $n^{\circ} 4.680$ de 2003, a Lei $n^{\circ} 11.105$ de 2005 e a Portaria $n^{\circ}$ 2.658 de 2003, como as principais normas que regulam a matéria. Ressalta-se que a Portaria $n^{\circ} 2.658$ não foi identificada pelas bases de dados através dos descritores utilizados.

O Decreto $n^{\circ} 4.680$ de 2003 refere-se aos

alimentos e ingredientes alimentares destinados ao consumo humano e animal, embalados ou a granel ou in natura, que contenham ou sejam produzidos a partir de organismos geneticamente modificados, com presença acima de $1 \%$ do produto.

Carvalho (2004) destaca que, mais importante do que o percentual de transgênicos é informar ao consumidor sobre a presença de OGM nos produtos consumidos. Além disso, o decreto determina ainda os órgãos competentes para executar a completa ficalização, designando o MAPA como responsável por fiscalizar toda a documentação fiscal no campo, a ANVISA como responsável pelo acompanhamento da indústria alimentícia e o Ministério da Justiça pela fiscalização da oferta de produtos aos consumidores (SALAZAR, 2011).

A Lei $n^{\circ} 11.105$ de 2005, em seu artigo 40, reafirma a obrigatoriedade da rotulagem de produtos destinados ao consumo humano ou animal que contenham ou que sejam produzidos a partir de organismos transgênicos ou derivados.

A Portaria $n^{\circ} 2.658$ de 2003 estabeleceu um símbolo como informação impressa que represente a origem transgênica ou não de determinado produto. Segundo essa Portaria, tais produtos devem trazer a letra "T" envolta por um triângulo com o fundo amarelo, além da expressão "pode conter produto transgênico" ou "pode conter ingrediente produzido a partir de produto transgênico", no caso de origem vegetal. Apesar desse símbolo ser considerado como sinal de 
alerta, perigo, não se pode deixar de considerar que a função da rotulagem é de informar ao consumidor sobre aspectos como a composição e a origem dos produtos.

Apesar do arcabouço legal, a rotulagem de alimentos que contem OGM é raramente cumprida no Brasil, havendo evidências de que alimentos destinados para o consumo humano no País contenham transgênicos (SALAZAR, 2011). Destaca-se que as empresas Cargil e a Bunge, cumpriram o decreto de rotulagem em seus óleos de soja somente após determinações judiciais (SALAZAR, 2011). Sem um controle efetivo é impossível atribuir diferenças entre os produtos geneticamente modificados e os tradicionais e, consequentemente, o impacto do consumo de OGM para a saúde humana (PELAEZ, [s/d]; MAGAÑA-GÓMEZ et al., 2008).

No cenário internacional, têm-se posições antagônicas com relação à rotulagem desses alimentos. Em termos gerais, os países podem ser divididos em 3 grupos. Primeiro, é o grupo composto por países que adotam uma regulamentação restrita, onde há rotulagem é obrigatória variando, somente, o percentual de tolerância desses produtos. Nessa condição está a União Europeia (UE), Austrália, China, Nova Zelândia, Japão, Rússia (GRUĖRE, 2006).

O segundo grupo é composto por países que adotam uma postura mais pragmática, com base no critério da ES, onde a rotulagem é voluntária. São países como os EUA, Argentina, Canadá e África do Sul (GRUĖRE, 2006).

Por último têm-se os países que ainda não adotaram uma regulamentação específica. Neste grupo está a maioria dos países em desenvolvimento (GRUĖRE, 2006).

Sobre a obrigatoriedade da rotulagem, enfatiza-se a existência de uma discussão sobre até onde a rotulagem obrigatória realmente transmite informações adequadas aos consumidores contribuindo para que estes escolham adequadamente $\mathrm{o}$ que consumir. $\mathrm{O}$ fato de existir na embalagem dos produtos um símbolo que o classifique como transgênico não terá a repercussão desejada se a sociedade não for informada sobre o que é um alimento transgênico (CARTER e GRUĖRE, 2003).

Independente das regulamentações internas de cada país, é importante dizer que existem três acordos internacionais que abordam diretamente a questão dos 
OGMs. São eles: o Codex Alimentarius, o Protocolo de Biossegurança e a Organização Mundial do Comércio (OMC) (GRUĖRE e RAO, 2007).

Segundo o Codex Alimentarius, órgão criado pela FAO e a OMS, cujas decisões não são vinculantes, inicialmente o entendimento era de que tais produtos devem seguir as normas da Organização Mundial do Comércio. A OMC defende que a informação quanto à transgenia de um produto não tem qualquer relevância para o consumidor do ponto de vista da segurança alimentar. Com isso, não só defende a não necessidade dessa informação quanto não permitem a rotulagem de alimentos que contenham ou são feitos a partir de OGMs (FAOMHO, 2001).

No entanto, a partir da $32^{a}$ reunião da Comissão do CODEX para Rotulagem de Alimentos (CCFL), ficou estabelecida a recomendação para a rotulagem quando (CODEX ALIMENTARIUS COMMISSION, 2011):

1) Esses alimentos e ingredientes alimentares forem obtidos a partir da tecnologia de modificação genética;

2) Houver mudança na composição ou no valor nutricional desse alimento quando comparado a sua contraparte convencional;

3) O alimento ou ingrediente alimentar conter proteína ou DNA resultante da tecnologia de modificação genética.

O Protocolo de Biossegurança defende o uso da rotulagem para fins de importações e exportação de sementes e alimentos geneticamente modificados e não para informar o consumidor final (PELAEZ, [s/d]).

Já a União Europeia, em razão da opinião pública majoritariamente contra o consumo dos transgênicos, determina um limite de tolerância de 0,9\% para a rotulagem desses produtos, exigindo rotulagem quando esse limite for ultrapassado (Resolução (EC) n 1829 e 1830 de 2003 e Diretiva 2001/18/EC). Em 1997 na UE foram desenvolvidos os primeiros requerimentos obrigando a rotulagem desses alimentos justificados pelo Princípio da Precaução (GRUĖRE, 2006).

A Diretiva 18 de 2001 aborda mais especificamente a questão da rastreabilidade e rotulagem dos transgênicos autorizados para produção e comercialização. Através dessa Diretiva, toda cadeia produtiva deve ser acompanhada para poder garantir a presença ou não de resíduos GM no produto final (THE EUROPEAN PARLIAMENT, 2001).

Similar à posição da UE tem-se uma gama de países que adotam regime de rotulagem obrigatória, no entanto com um percentual de tolerância menos rígido, 
como a Austrália, Brasil, China, Índia, Indonésia, Coréia do Sul, Malásia, Nova Zelândia, Noruega, Filipinas, Rússia, Arábia Saudita, Suíça, Tailândia e Japão (SAND, 2006).

Argentina e Canadá apoiam a posição norte americana, ou seja, acreditam que não há evidências científicas que comprovem os perigos à saúde e ao meio ambiente dos OGMs, com isso não tem por que proibi-los. Defendem ainda que não se podem exigir certezas indiscutíveis quanto à segurança alimentar (BAUMÜLLER, 2003).

O sistema de regulação dos transgênicos na Austrália é considerado um dos mais desenvolvidos, uma vez que abordam a avaliação da segurança alimentar e da rotulagem. As normas australianas exigem que todo alimento ou ingrediente GM seja rotulado no local onde ele adquiriu a modificação genética. Além disso, todo alimento produzido usando biotecnologia deve ser avaliado quanto sua segurança para o consumo humano e só depois disso é aprovado, ou não, para venda e consumo (BAUMÜLLER, 2003).

O estado atual em que se encontram regulamentados os organismos transgênicos no mundo nos faz pensar sobre a adequação desses dispositivos legais para a preservação da biodiversidade e saúde humana, assim como sua capacidade de precaução no que se refere aos limites éticos para a pesquisa e desenvolvimento científico e tecnológico aprovados. Além disso, as diferentes posições dos diversos países também podem repercutir com impactos importantes nos acordos internacionais, principalmente no que se refere à importação e exportação de sementes e gêneros alimentícios. Sendo assim, defende-se o acesso à informação como vital para a educação da sociedade (FROTA, 2009). Busca-se, com a rotulagem dos alimentos, informar ao consumidor sobre as características dos alimentos que ele pretende consumir, auxiliando-o assim, na escolha correta dos produtos.

Destaca-se que muitos países em desenvolvimento ainda não adotaram uma regulamentação específica para os transgênicos. Esse fato pode ser visto de maneiras distintas: ou eles estão aguardando uma regulamentação internacional única, ou estão aguardando as repercussões das políticas dos países que já adotaram uma posição (GRUÈRE, 2006). Sejam quais forem suas posições, é fundamental que alguma regulamentação seja adotada uma vez que os transgênicos já estão no mercado há mais de 10 anos. 


\section{Considerações finais}

Com base nos dados desse estudo pode-se concluir que houve um predomínio de normas no governo Lula e de autoria do Poder Executivo. Reconhecem-se também as limitações das bases de dados utilizadas uma vez que algumas normas, em vigor, não foram identificadas.

A regulamentação brasileira dos transgênicos é caracterizada por um processo de edições de medidas provisórias, com força de lei, que muitas vezes modificou a implementação de leis já aprovadas. O propósito dominante dessas MP foi de legalizar plantações ilegais, e que na prática facilitaram a ampliação do cultivo e uso de plantas transgênicas no Brasil. Mais da metade das normas produzidas referem-se direta ou indiretamente às Medidas Provisórias.

As normas em vigor colocam o Brasil numa posição intermediária entre a regulamentação restrita da UE e altamente flexível dos EUA. Ou seja, a regulamentação brasileira considera a necessidade de alguns testes antes de liberar uma variedade geneticamente modificada. A exigência desses testes cabe a instituição proponente da tecnologia ou outra por ela contratada. No entanto, além do conflito de interesse em si (interesse econômico versus encontrar possíveis efeitos adversos da tecnologia proposta), os estudos não só não atendem às normas, são de duvidosa qualidade cientifica e feitos fora do provável meio receptor do OGM, bem como grande parte deles não são publicados em revistas cientificas, o que dificulta o acesso à informação e o debate cientifico.

Com isso, as normas brasileiras não são cumpridas em sua íntegra. Além disso, o fato de cada país ter uma regulação diferente gera problemas de importação e exportação, onde os produtos transgênicos encontram barreiras legais. Assim, um produto é fabricado segundo as normas de seu país e quando é exportado, não está em conformidade com as normas do país comprador. Diante disso, é fundamental que todos os países sejam regidos com base em um único acordo internacional.

Na questão da rotulagem, a norma brasileira aborda com muita propriedade a defesa do direito a informação, do direito de escolha dos consumidores, assemelhando-se à posição europeia. No entanto muito ainda necessita ser feito para melhorar as estratégias de fiscalização do cumprimento das referidas normas. 


\title{
REGULATIONS ON BIO (IN) SECURITY IN BRAZIL: THE ISSUE OF THE TRANSGENIC FOOD
}

\begin{abstract}
:
This study aimed to analyze the Brazilian legislation on genetically modified organisms - GMOs (or GM). The standards were identified in databases and Sicon LEXML, both available at the Senate. We found 25 standards, mostly written by the executive branch under President Lula. The main topics discussed were planting, monitoring, marketing and labeling of GMOs. It is concluded that the legislative process in Brazil is mostly based on provisional measures which were designed to allow the marketing of GM soy planted illegally in the country until 2003. The Brazilian requirements regarding labeling resemble the European ones, but much still needs to be done to improve strategies for monitoring compliance. Relevant standards in Brazil were not identified by the databases used.
\end{abstract}

Keywords: GM. Regulation. Food safety legislation.

\section{REGLAMENTO DE BIO(IN)SEGURIDAD EN BRASIL: EL PROBLEMA DE LOS ALIMENTOS TRANSGÉNICOS}

\section{Resumen:}

Este estudio tuvo como objetivo analizar la legislación brasileña sobre los organismos genéticamente modificados - OGM (o transgénicos). Las normas fueron identificadas en bases de datos de SICON y LEXML, ambas disponibles en la página web del Senado de la Nación. Hemos encontrado 25 normas, en su mayoría escritos por el Poder Ejecutivo del gobierno Lula. Los principales temas tratados fueron la siembra, control, comercialización y etiquetado de los OMG. Llegamos a la conclusión de que la producción de leyes en Brasil se basa principalmente en medidas provisórias, cuyo principal objetivo era permitir la comercialización de la soja transgénica plantadas ilegalmente en el país hasta 2003. Los requisitos brasileños en materia de etiquetado se parecen a los de Europa, sin embargo todavía queda mucho por hacer para mejorar las estrategias de control del cumplimiento de las normas. Normas brasileñas relevantes no fueron identificadas por las bases de datos utilizadas.

Palabras clave: Transgénicos. Reglamentos. Seguridad alimentaria. Legislación. 


\section{Referências}

ALMEIDA JÚNIOR, A. R. de; MATTOS, Z. P. de B. llusórias sementes. Ambiente e Sociedade. v.8, n.1, p.101-120, 2005.

AMORIM, N. O. O Poder Executivo, centro da gravidade do sistema político Brasileiro. In: AVELAR, L.; CINTRA, A. O. (orgs). Sistema Político brasileiro: uma introdução. Rio de Janeiro: Fundação Konrad-Adenauer-Stiftung; São Paulo: Fundação Unesp, 2004.

ARBIX, G. Biotecnologia Sem Fronteiras. Novos Estudos, São Paulo, CEBRAP, v.78, p.5-10, 2007.

ARIS, A.; LEBLANC, S. Maternal and fetal exposure to pesticides associated to genetically modified foods in Eastern Townships of Quebec, Canada. Reprod Toxicol.; v.31, n.4, p.528-533, 2011.

BAPTISTA, T. W. de F. Análise da produção legislativa em saúde no Congresso Nacional brasileiro (1990-2006). Cad. Saúde Pública, v.26, n.1, p. 97-109, 2010.

\footnotetext{
BAUMÜLLER, H. Domestic Import Regulations for Genetically Modified Organisms and their Compatibility with WTO Rules. 2003. Disponível em: http://www.tradeknowledgenetwork.net. Acesso em: 23 nov. 2009.
}

BOSCHI, R. R; LIMA, M. R. S. de. O Executivo e a construção do estado no Brasil. Do desmonte da Era Vargas ao novo intervencionismo regulatório. In: VIANNE, L. W. (org). A democracia e os três poderes no Brasil. Belo Horizonte, UFMG, Rio de Janeiro IUPERJ/FAPERJ, 2003.

BRASIL. Governo do Estado de Santa Catarina. Dispõe sobre o plantio, cultivo, pesquisa, indústria e comércio de organismos geneticamente modificados no Estado de Santa Catarina, cria o Conselho Técnico Catarinense de Biossegurança - CTCBio - e adota outras providências. Lei $n^{0} 12.128$ de 16 de janeiro de 2002. Santa Catarina: Governo Estadual; $2002 . \quad$ Disponível em: <http://200.192.66.20/alesc/docs/2000/..\%5C2002\%5C12128_2002_leis.doc>. Acesso em: 17 jan. 2012.

$\begin{array}{lcccr} & \begin{array}{c}\text { Governo } \\ \text { de }\end{array} & \begin{array}{c}\text { Federal. Constituição da } \\ \text { outubro }\end{array} & \text { República Federativa do } & \text { Brasil } \\ \text { <http://www.senado.gov.br/sf/legislacao/const/>. Acesso em: } 10 \text { jan. } 2009 . & \text { em: }\end{array}$


Comissão Técnica Nacional de Biossegurança. Aprovações comerciais. Parecer $n^{\circ}$ 513/2005 dispões sobre a Liberação Comercial de Algodão Geneticamente Modificado resistente a Insetos Evento 531 - Processo 01200.001471/2003-01. 2005. Disponível em: <http://www.ctnbio.gov.br/index.php/content/view/12526.html>. Acesso em: 12 abr. 2010.

Comissão Técnica Nacional de Biossegurança. Aprovações comerciais. Parecer Técnico $n^{\circ}$ 099/2004 dispõe sobre a Liberação Comercial da Vacina VAXXITEK MD/IBD - Processo 01200.005090/2003-92. 2003. Disponível em: $<$ http://www.ctnbio.gov.br/index.php/content/view/11027.html>. Acesso em: 11 set. 2011.

$\begin{array}{cccc}\text { comerciais. } & \text { Comissão Técnica Nacional de Biossegurança. Aprovações } \\ \text { 2005c. } & \text { Disponível }\end{array}$ <http://www.ctnbio.gov.br/index.php/content/view/12482.html>. Acesso em 10 ago. 2011.

Comissão Técnica Nacional de Biossegurança. Aprovações comerciais. Parecer $n^{\circ}$ 987/2007 dispões sobre a liberação comercial do Milho Geneticamente Modificado tolerante a herbicida Evento T25 - Processo 01200.005154/1998-36. 2007. Disponível em: <http://www.ctnbio.gov.br/index.php/content/view/10971.html>. Acesso em: 12 abr. 2010.

Congresso Nacional. Lei 11.460 de 21 de março de 2007. Dispõe sobre o plantio de organismos geneticamente modificados em unidades de conservação. Diário Oficial da União, Brasília. 22 mar. 2007a.

. Congresso Nacional. Lei 10.688 de 13 de junho de 2003. Estabelece normas para a comercialização da produção de soja da safra de 2003 e dá outras providências. Diário Oficial da União, Brasília. 16 jun. 2003e.

Congresso Nacional. Lei 11.092 de 12 de janeiro de 2005. Dispõe sobre o plantio e comercialização da produção de soja GM da safra de 2005. Diário Oficial da União, Brasília. 13 jan. 2005b.

Congresso Nacional. Lei 11.105 de 24 de março de 2005 sobre as normas de segurança e mecanismos de fiscalização de atividades que envolvam organismos geneticamente modificados - OGM e dá outras providências. Diário Oficial da União, Brasília. 28 mar. 2005a. 
- Congresso Nacional. Lei 8974 de 5 de janeiro de 1995 sobre as normas de segurança e mecanismos de fiscalização de atividades que envolvam organismos geneticamente modificados - OGM e dá outras providências. Diário Oficial da União, Brasília. 06 jan. 1995.

Congresso Nacional. Lei 10.184 de 15 de dezembro de 2003. Estabelece normas para o plantio e comercialização da produção de soja da safra de 2004, e dá outras providências. Diário Oficial da União, Brasília. 16 dez. $2003 f$.

. Congresso Nacional. Medida Provisória 327 de 31 de outubro de 2006. Dispõe sobre o quorum da CTNBio e plantação de OGM em áreas de proteção. Diário Oficial da União, Brasília. 1 nov. 2006.

. Congresso Nacional. Medida Provisória 113 de 26 de março de 2003. Dispõe sobre comercialização da produção de soja da safra de 2003. Diário Oficial da União, Brasília. 27 mar. 2003c.

Congresso Nacional. Medida Provisória 131 de 25 de setembro de 2003. Dispõe sobre comercialização da produção de soja da safra de 2004. Diário Oficial da União, Brasília. 16 dez. 2003d.

. Congresso Nacional. Medida Provisória 223 de 14 de outubro de 2004. Dispõe sobre comercialização da produção de soja da safra de 2005. Diário Oficial da União, Brasília. 15 out. 2004a.

. Ministério da Justiça. Lei 8.078 de 11 de setembro de 1990. Dispõe sobre o Código de Defesa do Consumidor (CDC). Diário Oficial da União 1990, 12 set. Brasília.

. Ministério da Justiça. Portaria 2658 de 22 de dezembro de 2003 sobre o emprego do símbolo transgênico. Diário Oficial da União, Brasília. 26 dez. 2003b.

Ministério da Saúde. Decreto 4.680 de 24 de abril de 2003 sobre o direito à informação quanto aos alimentos e ingredientes alimentares destinados ao consumo humano ou animal que contenham ou sejam produzidos a partir de organismos geneticamente modificados. Diário Oficial da União, Brasília. 25 abr. $2003 a$. 
Presidência da República. Legislação: Medidas Provisórias. Disponível em: $\quad$ <http://www4. planalto.gov.br/legislacao/legislacao-1/medidas-provisorias>. Acesso em: 11 set. 2011.

. Presidente da República. Mensagem 164 de 21 de março de 2007. Estabelece veto parcial, por contrariedade ao interesse público, ao Projeto de Lei de Conversão no ${ }^{\circ}$ 29, de 2006. Diário Oficial da União 2007b, 22 mar. Brasília.

CAMARA, M. C. C.; MARINHO, C. L. C.; NODARI, R. O.; GUILAM, M. C. R. Transgênicos: avaliação da possível (in)segurança alimentar através da produção científica. História, Ciências, Saúde - Manguinhos, v.16, n.3, p.669-681, 2009.

CAMARA, M. C. C. Regulamentação e atuação do Governo e do Congresso Nacional sobre os alimentos transgênicos no Brasil: uma questão de (in)segurança alimentar. Tese de Doutorado. Escola Nacional de Saúde Pública, Fiocruz, 2012.

CARTER C. A., GRUĖRE G. P. Mandatory Labeling of Genetically Modified Foods: Does it Really Provide Consumer Choice? AgBioForum, v.6, n.1\&2, p.68-70, 2003.

CARVALHO, L. E. Rotulagem de transgênicos: lipídeos, genes (sem sempre), ideologias, paixões e interesses como ingredientes. 2004. Disponível em: <http://acd.ufrj.br/consumo/leituras/ig.htm>. Acesso em: 22 set. 2009.

CODEX ALIMENTARIUS COMMISSION. Report of the thirty second session of the codex committee on methods of analysis and sampling. 2011. Disponivel em: http://www.codexalimentarius.net/web/archives.jsp?lang=en Acesso em: $06 \mathrm{dez}$. 2011.

DAVISON, J. GM plants: science, politics and EC regulations. Plant Science. v.178, p. 94-98, 2010.

DOLABELLA, R. H. C.; ARAÚJO, J. C. de; FARIA, C. R. S. M. A lei de biossegurança e seu processo de construção no congresso nacional. Cadernos ASLEGIS, v. 25, p.63-75, 2005.

DULCl, O. S. A incômoda questão dos partidos no Brasil. Notas para o debate da reforma política. In: BENEVIDES, M. V. et al. (org). Reforma Política e Cidadania. São Paulo: Ed. Perseu Abramo, 2003. 
EUROPEAN COMMISSION. EU policy on biotechnology. 2006. Disponível em: $<$ HTTP://europa.eu.int/comm/environmental/env-informa>. Acessado em: 20 jul. 2011.

FAO/WHO. Codex Ad Hod Task Force on foods derived from biotechnology. Codex Alimentarius Commission, Food and Agriculture Organization of the United Nations. Report of a joint FAO/WHO food standards programme. 2001. Disponível em: ftp://ftp.fao.org/codex/alinorm01/al0134al.pdf Acesso em: 22 set. 2009.

FERMENT, G. Biossegurança e princípio da precaução. O caso da França e da EU. Brasília: Ministério do Desenvolvimento agrário, 2008.

FLEISCHER, D. Os partidos políticos. In: AVELAR, L., CINTRA, A. O. (orgs). Sistema Político brasileiro: uma introdução. Rio de Janeiro: Fundação KonradAdenauer-Stiftung; São Paulo: Fundação Unesp, 2004.

FROTA, E. B. A participação popular do consumidor como instrumento de defesa ambiental. $\mathrm{O}$ caso da rotulagem dos alimentos transgênicos. Jus Navigandi v.13, n.2282, 2009.

GRUĖRE G. P., RAO S. A Review of International Labeling Policies of Genetically Modified Food to Evaluate India's Proposed Rule. AgBioForum v.10, n.1, p. 51-64, 2007.

GRUĖRE, G. P. An analysis of trade relates international regulations of genetically modified food and their effects on developing countries. EPT Discussion. Paper 147. International Food Policy Research Institute (IFPRI), February 2006.

LACEY, H. Há alternativas ao uso dos transgênicos. Novos Estudos, São Paulo, CEBRAP, v.78, p.31-39, 2007.

A controvérsia sobre os transgênicos: Questões científicas e éticas. São Paulo: Idéias \& letras. 2006.

LEITE, M. A paralisia no debate sobre transgênicos e meio ambiente. Novos Estudos, São Paulo, CEBRAP, v.78, p.41-47, 2007.

LIMA, J. A. de O.; CICILIATI, F. (Ed). LexML Brasil. Apresentação. Brasília. 2008. Disponível em: <http://projeto.lexml.gov.br/documentacao/Apresentacao.pdf/view>. Acesso em 02/jul/2011. 
MAGAÑA-GÓMEZ, J. A.; BARCA, L. A.; CALDERÓN, A. N. de. Risk assessment of genetically modified crops for nutrition and health. Nutrition Reviews. v. 67, n.1, p. 1-16, 2008.

MARINHO, C. L. C.; MINAYO-GOMEZ, C. Decisões conflitivas na liberação dos transgênicos no Brasil. São Paulo em Perspectiva, v.18, n. 3, p. 96-102, 2004.

PELAEZ, V. O estado de exceção no marco regulatório dos organismos geneticamente modificados no Brasil. [s.d]. Disponível em: http://www.sober.org.br/palestra/6/848.pdf. Acesso em: 23 set. 2009.

PELAEZ, V.; SBICCA, A. Organismos Geneticamente Modificados: a face não revelada pela ciência. Disponível em: < $\underline{w w w . a m b i e n t e-a u g m . u f s c a r . b r / u p l o a d s / A 3-~}$ 080.pdf>. Acesso em: 16 mar. 2010.

PESSANHA, C. O poder executivo e o processo legislativo nas constituições brasileiras. Teoria e prática. In: VIANA, L. W (org). A democracia e os três poderes no Brasil. Belo Horizonte: Editora UFMG, Rio de Janeiro: IUPERJ/FAPERJ, 2003.

PESSANHA, L.; WILKINSON, J. Transgênicos, recursos genéticos e segurança alimentar: o que está em jogo nos debates? São Paulo: Armazém do Ipê (autores associados). 2005.

RIZZI, A.; SORLINI, C.; DAFFONCHIO, D. Practicality of detection of genetically modified organisms (GMOs) in food. AgBiotech Net. v. 6, n. ABN 130, p. $1 \mathrm{~N}-9 \mathrm{~N}$, 2004.

SALAZAR, A. A informação sobre alimentos transgênicos no Brasil. In: ZANONI, M.; FERMENT, G. (Org.). Transgênicos para quem? Agricultura, Ciência e Sociedade. Brasilia: Ministério do Desenvolvimento Agrário, 2011.

SAND, P. H. Labelling Genetically Modified Food: The Right to Know. RECIEL v.15, n.2, p.185-192, 2006.

SANTOS, M. H. de C. Governabilidade, governança e democracia: criação de capacidades governativa e relações executivo-legislativo no Brasil Pós-Constituinte. Revista de Ciências Sociales. v. 30, n.3, 1997. 
THE EUROPEAN PARLIAMENT. Directive 2001/18/EC. 2001. Disponível em: http://www.biosafety.be/PDF/2001 18.pdf. Acesso em: 06 dez. 2011.

VIANA, N. O,; TEIXEIRA, O. F. Breve análise sobre Bioética e Biodireito. Jus Societas, v.2, n.3, p. 1-15, 2009.

VICTORINO, V. I. Participação popular na construção de biossegurança no Brasil: a questão dos transgênicos. Revista de Ciencias Sociales CONVERGENCIA, México, Universidad Autonome Del Estado del México 2004; 11(35):107-127.

ZANONI, M.; MELGAREJOK L.; NODARI, R. O.; DAL SOGLIO, F. K.; KAGEYAMA, P. Y.; FERRAZ, J. M.; BRACK, P.; CHOMENKO, L.; DEFFUNE, G. O Biorrisco e a Comissão Técnica Nacional de Biossegurança: Lições de uma experiência. In: ZANONI, M.; FERMENT, G. (Org.). Transgênicos para quem? Agricultura, Ciência e Sociedade. Brasilia: Ministério do Desenvolvimento Agrário, 2011.

Artigo:

Recebido em: Outubro/2012

Aceito em: Maio/2013 